\title{
CAPTIVE BREEDING OF THREATENED ORNAMENTAL FISH SPECIES OF MANIPUR, INDIA
}

\author{
YUREMBAM MOTILAN ${ }^{1}$, RAJKUMAR RADHAKRISHORE ${ }^{2 *}$ and WAIROKPAM WANGTHOINGANBA ${ }^{1}$
}

${ }^{\prime}$ Department of Life Sciences, Manipur University, Canchipur (Manipur)

${ }^{2}$ Department of Zoology, Manipur College, Singjamei, Imphal (Manipur)

\begin{abstract}
Pethia manipurensis, categorized as endangered and Devario acuticephalus and Pethia khugae, both as vulnerable have been collected from the wild and successfully induced to breed by using WOVA-FH, a synthetic gonadotropin releasing hormone analogue (SGRRH). Injection $0.3 \mathrm{ml} \mathrm{kg}^{-1}, 0.5 \mathrm{ml} \mathrm{kg}^{-1}$ and $0.5 \mathrm{ml} \mathrm{kg}^{-1}$ were effective in case of Pethia manipurensis, Pethia khugae and Devario aceuticephalus respectively. Crude Pituitary Extract injection (a) $0.5 \mathrm{ml} \mathrm{kg}^{-1}$ was also effective in these three threatened species.
\end{abstract}

Key words : Captive breeding, Ornamental fish species.

\section{INTRODUCTION}

Freshwater fish subfamily Cyprinidae includes barbs which are characteristic in having large scales, bright colours, schooling behaviour and are easy to maintain and breed which made them popular in the aquarium trade (Clade et al.,1997). Aquacultural production of ornamental fishes now-a-days is mostly focused on freshwater species, and this usually leads to the decline in the wild population of the species (Tlusty, 2002). Collection of the fishes for the purpose of ornamental fish trade would be depleting the wild stock.

An endangered barb, Pethia manipurensis, locally known as Ngakameingangbi in Manipuri is used in the preparation of 'Hentak' and 'Ngari', two important fermented fish products which enhance the flavour of Manipuri dishes (Sarojnalini and Vishwanath,1988). Pethia manipurensis is characterized by a small elongate Pethia species with two black spots on the body, a shoulder spots on $3^{\text {rd }}$ and $4^{\text {th }}$ lateral line scale rows and a caudal spot on $17^{\text {th }}$ and $18^{\text {th }}$ lateral line scales; scales edged dark; without barbels; ossified and denticulated dorsal spiny ray; incomplete lateral line with 2425 scales. The species is endemic to Chindwin basin (Vishwanath,2007). The fish is euryphagic in nature, feeding mainly on insects, nymphs, green algae, larvae, diatoms, worms, zooplankton, organic debris etc. In their natural habitats the species breed in ponds, lakes, paddy fields, rivers, streams and small pits. Pethia khugae, locally also known as 'Phabounga' in Manipuri is characterized by the following combination of characters: dorsal edge plain, its spine serrated posteriorly with 10-12 serrae; predorsal scales 11-12; lateral line incomplete with 8 -11 pores scales; $28-30$ scales in lateral-line row, black blotch on caudal peduncle at level of one scale behind posterior end of anal origin. Pethia khugae inhabits the Khuga river, a faster clear-water (Linthoingambi and Vishwanath,2007). The species is also endemic to Chindwin basin (Vishwanath et al.,2007). The fish is also euryphagic in nature, feeding mainly on insects, nymphs, green algae, larvae, diatoms, worms, zooplankton, organic debris etc. The species generally breed in rivers and streams.
Devario acuticephalus is characterized by very small body; a wide stripe tapering posteriorly and ending at caudal fin base, its anterior portion less pigmented and margins diffused up to the vertical level of the first anal-fin insertion; lateral line absent; dorsal fin with 7 rays and anal fin 9-10 rays; indistinct cleithral spot. The species was first described by Hora,1921 (Fang and Kulander,2009) as Danio (Branchiodanio) acuticephala from Yairibok, Chindwin drainage, Manipur. The species, now accommodated under the genus Devario (Fang and Kulander,2009) is endemic to the Chindwin basin (Vishwanath et al.,2007).

Pethia manipurensis, D.acuticephalus and Pethia khugae, of which the first one categorized as endangered and the remaining two, as vulnerable (Vishwanath et al.,2010) fulfil all the characters of ornamental fishes. Approximately $90 \%$ of freshwater ornamental fish are bred in captivity (Chao et al.,2011). Puntius ganionotus and Thai carp have been artificially induced to breed respectively by Liley \& Tan (1985) and Sukumaravin et al. (2006). Effect of ultrasonic sound on breeding performance of Puntius sarana was also done by Maily et al. (2007). Motilan et al. (2013) also successfully induced Puntius chola to breed using WOVA-FH. The above named three species have not been attempted so far.

In view of the conservation and sustainable utilization of the fishes, captive breeding is essential. Thus, objective of the experiment is induce the species to breed by using WOVA-FH, a synthetic gonadotropin releasing hormone analogue (SGnRH) prepared and marketed by WOCKHARDT (Biostat Agrisciences, a division of Wochardt Life Sciences Limited Mumbai India) and Crude Pituitary Extract (CPE).

\section{MATERIAL AND METHODS}

Collection of fishes : Fishes were collected from different water bodies of Manipur by electro fishing equipments, gillnet, scoop net and by drying water at pre-monsoon \& postmonsoon seasons. Fish were transported to Fishery laboratory of the Department of Life Sciences, Manipur University in ox- 
ygen filled polythene begs following the methods of Esther (Esther and Vernallen,2005).

Identification of fishes : Fishes were preserved at $10 \%$ formalin. Fishes were preserved at Manipur University Museum of Fish (MUMF). Measurements were taken point-to-point with digital callipers to the nearest $0.01 \mathrm{~mm}$. Fishes were identified based on Vishwanath et al. (2007).

Analysis of physico-chemical parameters of water : Temperature of air and water were measured using a mercury thermometer. The $\mathrm{pH}$ of water was measured by digital $\mathrm{pH}$ meter and dissolved oxygen (DO) was measured by Winkler's Method (1888). Free $\mathrm{CO}_{2}\left(\mathrm{FCO}_{2}\right)$, Carbonate $\left(\mathrm{CO}^{-}\right)$alkalinity and Bicarbonate alkalinity $\left(\mathrm{HCO}^{3}\right)$ were measured by Welch Method(1948)

Acclimatization strategy : Fishes were kept in starvation for one day. Water in the aquaria was constantly aerated and DO was monitored every four hours to see that a minimum of 8 ppm is maintained. Direct lighting is not done; instead, indirect lighting using earthen pot with holes was used. Feeding was done after two days. Lighting was done twelve to fourteen hour of light per day of light intensity $0.52-0.5$ watts per litre following Esther 2005.

Culture technique : Fishes were cultured in aquarium sizes of $90 \times 45 \times 30 \mathrm{~cm}$. Every day feed the fish, check the temperature and look to make sure all the fish are healthy and not displaying any deviant behaviour.

Analysis of maturity and sexual dimorphism : Maturities of fishes were assessed on the basis of genitalia, oozing milt, swollen vent, body colouration and roughness body and pectoral fin.

Induced breeding : Induced breeding experiment was conducted on 20 gravid females and 40 males $(n=60)$ in all the cases. Synthetic hormone WOVA-FH was injected at the rate of $0.2,0.3$ and $0.4 \mathrm{ml} \mathrm{kg}^{-1}$ in case of P.manipurensis, $0.3,0.4$ and $0.5 \mathrm{ml} \mathrm{kg}^{-1}$ in case of P.khugae and $0.3,0.4$ and $0.5 \mathrm{ml} \mathrm{kg}^{-1}$ D.aceuticephalus and $0.5 \mathrm{ml} \mathrm{kg}^{-1} \mathrm{CPE}$ was also injected in all the species at the ratio of $1: 2$ female and male by an insulin sy- ringe (standard U-10 i.e., $1 \mathrm{ml}$ of fluid in 100 standard units) on the body below the base of the dorsal fin. After injection, the fishes were released in an aquarium $(90 \times 45 \times 30 \mathrm{~cm}$ size). The breeding environmental conditions are as shown in Table.1.

Analysis of egg production and spawning : After spawning the fecundity of each female was determined by randomly taking samples of eggs in a $1 \mathrm{ml}$ graduated tube. Total number of eggs in $1 \mathrm{ml}$ was counted and was multiplied by total volume of egg released. Fertilization rates of eggs were determined by randomly taking a sample of approximately 100 eggs in a Petri dish. Only the fertilized eggs with an intake nucleus were counted for the percentage of fertilization. The significant effect of WOVA-FH on the egg production, fertilization rate and hatching rate were calculated by analysis of variance (ANOVA) with a statistical software packaged SPSS version 17.0. The significant of the effects on the investigating traits was checked by F-test. A probability level of 0.05 was utilized to account for the statistical significance.

Hatchling development : The fry were raised by feeding on fine powdered food (Sera micron), Tubifex worm powder, and small life foods such as planktons collected from the pond by plankton net.

\section{RESULTS AND DISCUSSION}

\section{Identification and Maturity :}

Pethia manipurensis : Fishes got matured at 2-3 g and standard length of 38-40 mm. Males were colourful; genital papilla is rather pointed, ripe male ooze milt when their belly is gently pressed. The females have smooth pectoral fin on touching, and have swollen vent, and bulging in mature forms.

Pethia khugae : Fishes got matured at 6-7 g and standard length of 42-45 $\mathrm{mm}$. Males were colourful; tuberculation on opercular region, genital papilla is rather pointed, ripe male ooze milt when their belly is gently pressed. The females have smooth pectoral fin on touching, and have swollen vent, and bulging in mature forms.

Table. 1 Physico-chemical parameters of the aquarium system.

\begin{tabular}{lcccccc}
\hline Atm. temp. $\left({ }^{\circ} \mathbf{C}\right)$ & Water temp. $\left({ }^{\circ} \mathbf{C}\right)$ & $\mathbf{p H}$ & DO $(\mathbf{p p m})$ & FCO2 (ppm) & Carb.alk (ppm) & Bicarb.alk (ppm) \\
\hline $25 \pm 4.0^{\circ} \mathrm{C}$ & $23 \pm 2{ }^{\circ} \mathrm{C}$ & $6.8 \pm 0.9$ & $7.2 \pm 2.0$ & $5 \pm 4$ & $3 \pm 2$ & $26 \pm 4$ \\
\hline
\end{tabular}

Table. 2 Result of induced breeding experiment of Pethia manipurensis by graded doses administration equally to males and females $0.3 \mathrm{ml} \mathrm{kg}{ }^{-1}$ body weight.

\begin{tabular}{cccccl}
\hline Treatment $\left(\mathbf{m l ~ k g}^{-1}\right)$ & Egg production & Spawning rate & Fertilization rate (\%) & Hatching rate (\%) & Remark \\
\hline 0.2 & $918.125 \pm 123.125^{\mathrm{a}}$ & $43.24 \pm 1.75^{\mathrm{a}}$ & $72.5 \pm 7.59^{\mathrm{a}}$ & $76.5 \pm 3.5$ & Partial spawning \\
0.3 & $996.5 \pm 146.5^{\mathrm{b}}$ & $100^{\mathrm{b}}$ & $83.2 \pm 3.25^{\mathrm{b}}$ & $82.75 \pm 3.25$ & Complete spawning \\
0.4 & $822 \pm 162^{\mathrm{c}}$ & $100^{\mathrm{b}}$ & $67.75 \pm 5.25^{\mathrm{a}}$ & $77.25 \pm 12.75$ & Complete spawning \\
$0.5 \mathrm{CPE}$ & $930.5 \pm 122^{\mathrm{d}}$ & $100^{\mathrm{b}}$ & $71.25 \pm 3.75^{\mathrm{a}}$ & $78.75 \pm 2.75$ & Complete spawning \\
0 & 0 & 0 & 0 & 0 & No spawning \\
\hline
\end{tabular}


Devario aceuticephalus : Fishes got matured at 1.5-2 g body weight and standard length of 35-40 $\mathrm{mm}$. Male and female were identified from distinct sexual dimorphism, adult female were typically heavier bodied and little larger than males. Males were more elongated and more colourful in the caudal region.

Determination of optimum doses of WOVA-FH : Colouration of fishes increased after the injection of hormone. Hormonal responses were observed in 4-6 hour, 5-6 and 6-8 hour after injection in case of Pethia manipurensis, Pethia khugae and Devario aceuticephalus respectively. None of the control fishes spawned, however all the fishes injecting hormone WOVA-FH@ 0.2, 0.3 and $0.4 \mathrm{ml} \mathrm{kg}^{-1}$ spawned successfully in case of Pethia manipurensis, $0.3,0.4$ and $0.5 \mathrm{ml} \mathrm{kg}^{-1}$ spawned successfully in case of P.khugae and 0.3,0.4 and 0.5 $\mathrm{ml} \mathrm{kg}{ }^{-1}$ spawned successfully in case of D.acuticephalus.
Effect of WOVA-FH and CPE on egg production, fertilisation and hatching : Analysis of variance showed a significant effect in case of the two species $(\mathrm{P}<0.5)$ of hormone doses on egg output but $(\mathrm{P}<0.5)$ the rate of fertilization was not significantly different between the treatment $(\mathrm{P}<0.5)$. The optimum doses of WOVA-FH i.e., $0.3 \mathrm{ml} \mathrm{kg}^{-1}$ led to $100 \%$ spawning in Pethia manipurensis, $0.5 \mathrm{ml} \mathrm{kg}^{-1}$ lead to $100 \%$ and $0.5 \mathrm{ml} \mathrm{kg}^{-1}$ led to $100 \%$ in Devario aceuticephalus. The spawning rate and number of egg production in the fish treated with CPE or $0.5 \mathrm{ml} \mathrm{kg}^{-1}$ were not statically different in Pethia manipurensis, Pethia khugae and Devario aceuticephalus (Tables.2,3\&4).

Development of hatchling : Pethia manipurensis and Pethia khugae hatchling took 20-26 days for development from fry to fingerlings stage after fertilisation and Devario aceuticephalus attained fingerling stage between 23-28 days.

Table. 3 Result of induced breeding experiment of Pethia khugae by graded doses of WOVA-FH administration equally to males and females $0.5 \mathrm{ml} \mathrm{kg}^{-1}$ body weight.

\begin{tabular}{cccccl}
\hline Treatment $\left(\mathbf{m l ~ k g}^{-1}\right)$ & Egg production & Spawning rate & Fertilization rate (\%) & Hatching rate (\%) & Remark \\
\hline 0.3 & $825.29 \pm 58.04^{\mathrm{a}}$ & $42.75 \pm 3.25^{\mathrm{a}}$ & $89.32 \pm 1.32$ & $44.75 \pm 1.75^{\mathrm{a}}$ & Partial spawning \\
0.4 & $1326.6 \pm 143.33^{\mathrm{b}}$ & $68.15 \pm 12.5^{\mathrm{b}}$ & $88.75 \pm 1.75$ & $71 \pm 1^{\mathrm{b}}$ & Partial spawning \\
0.5 & $1775 \pm 100^{\mathrm{c}}$ & $100^{\mathrm{c}}$ & $90.75 \pm 0.75$ & $91 \pm 2^{\mathrm{c}}$ & Complete spawning \\
$0.5 \mathrm{CPE}$ & $1728.75 \pm 77.5^{\mathrm{d}}$ & $100^{\mathrm{c}}$ & $90.75 \pm 1.25$ & $83.5^{\mathrm{d}}$ & Complete spawning \\
0 & 0 & 0 & 0 & 0 & No spawning \\
\hline Values are mean $\pm \mathrm{SEM}(\mathrm{n}=5) ;$ different subscript letters indicate significant difference $(\mathrm{p}<0.05)$. Spawning rate $=$ Number of fish spawned/total number of fish
\end{tabular}

Values are mean $\pm \operatorname{SEM}(\mathrm{n}=5)$; different subscript letters indicate significant difference $(\mathrm{p}<0.05)$. Spawning rate $=$ Number of fish spawned/total number of fish injected x 100 ; Egg production = number of egg released/g body weight of female; Fertilization rate $(\%)=$ Total number of eggs having faint streak/total number of eggs in sample x 100; Hatching rate $(\%)=$ Total number of hatched eggs as a percentage of tail of tail bud embryos.

Table. 4 Result of induced breeding experiment of Devario acuticephalus by graded doses of WOVA-FH administration equally to males and females $0.5 \mathrm{ml} \mathrm{kg}^{-1}$ body weight.

\begin{tabular}{|c|c|c|c|c|c|}
\hline Treatment $\left(\mathrm{ml} \mathrm{kg}^{-1}\right)$ & Egg production & Spawning rate & Fertilization rate $(\%)$ & Hatching rate $(\%)$ & Remark \\
\hline 0.3 & $264 \pm 14.54^{\mathrm{a}}$ & $41 \pm 4.27^{\mathrm{a}}$ & $43 \pm 3.1$ & $44.25 \pm 1.7^{\mathrm{a}}$ & Partial spawning \\
\hline 0.4 & $278 \pm 15.67^{\mathrm{al}}$ & $82.75 \pm 2.75^{\mathrm{b}}$ & $73 \pm 3.2$ & $71.25 \pm 1.5^{\mathrm{b}}$ & Complete spawning \\
\hline 0.5 & $310 \pm 11.12^{\mathrm{al}}$ & $100^{c}$ & $88.25 \pm 2.06$ & $90.75 \pm 0.95^{\mathrm{c}}$ & Complete spawning \\
\hline $0.5 \mathrm{mg} \mathrm{CPE}$ & $288 \pm 9.38^{\mathrm{c}}$ & $100^{\mathrm{c}}$ & $87.25 \pm 2.75$ & $85.25 \pm 1.25^{\mathrm{d}}$ & Complete spawning \\
\hline $0.5 \mathrm{ml} 0.7$ saline & 0 & 0 & 0 & 0 & No spawning \\
\hline
\end{tabular}

Values are mean \pm SEM $(\mathrm{n}=5)$; different subscript letters indicate significant difference $(\mathrm{p}<0.05)$. Spawning rate $=$ Number of fish spawned/total number of fish
injected $\mathrm{x} 100 ;$ Egg production $=$ number of egg released $/ \mathrm{g}$ body weight of female; Fertilization rate $(\%)=$ Total number of eggs having faint streak $/$ total number of eggs in sample $\mathrm{x} 100$; Hatching rate $(\%)=$ Total number of hatched eggs as a percentage of tail of tail bud embryos.

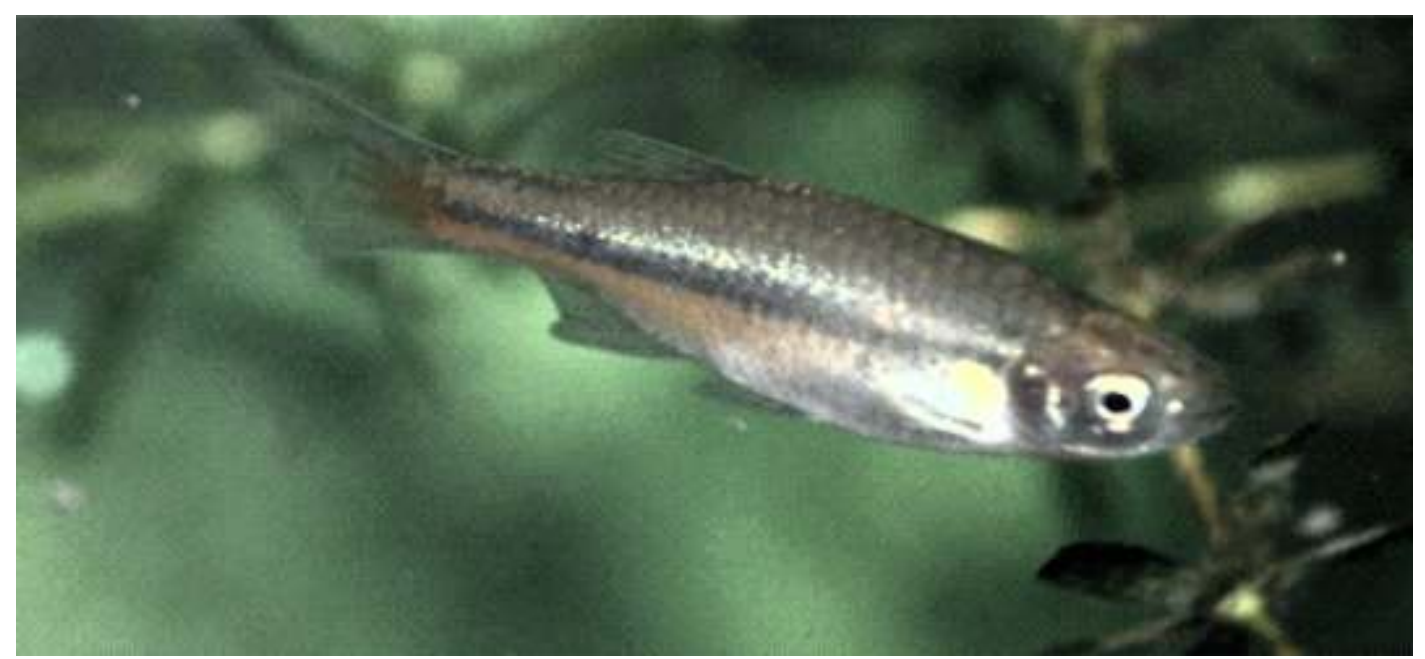

Fig. 1 Devario acuticephalus. 
Breeding behaviour of fish is controlled by various environmental factors such as light, temperature, $\mathrm{pH}, \mathrm{DO}$ and meteorological condition (Mani and Pandy,2007). Secretion of gonadotropic hormone and gene expression is controlled by the environmental factors (Ralston and Shaw,2008). However, the optimum environmental condition for natural breeding is not available in the aquarium. Hence, most of the fish lost their natural breeding behaviour. WOVA-FH injection was effective in spawning of Pethia manipurensis, Pethia khugae and D.aceuticephalus. Synthetic hormone WOVAFH injection at the doses of $0.3 \mathrm{ml} \mathrm{kg}{ }^{-1}, 0.5 \mathrm{ml} \mathrm{kg}^{-1}$ and $0.5 \mathrm{ml}$ $\mathrm{kg}^{-1}$ body weight by-pass the environmental factors and insure complete spawning of the fishes in Pethia manipurensis, Pethia khugae and Devario aceuticephalus. In case of Pethia manipurensis egg production was maximum rate at the doses of $0.3 \mathrm{ml} \mathrm{kg}^{-1}$, while the egg production of Pethia khugae and Devario aceuticephalus were maximum rate at the dose of 0.5 $\mathrm{ml} \mathrm{kg} \mathrm{kg}^{-1}$. CPE injection @ of $0.5 \mathrm{ml} \mathrm{kg}^{-1}$ was also effective in complete spawning of these three threatened species. Thus, the present study is fulfilled and complete spawning with the administration of synthetic hormone WOVA-FH at the doses of $0.3 \mathrm{ml} \mathrm{kg}{ }^{-1}, 0.5 \mathrm{ml} \mathrm{kg}^{-1}$ and $0.5 \mathrm{ml} \mathrm{kg}^{-1}$ and CPE @ $0.5 \mathrm{ml} \mathrm{kg}$ in Pethia manipurensis, Pethia khugae and D.aceuticephalus respectively. Requirement of synthetic hormone dose for spawn production is different in case of D.aceuticephalus and Pethia khugae as compare to Pethia manipurensis due to their different physiological condition. Devario aceuticephalus and Pethia khugae require relatively large dose of synthetic hormone to counteract the greater change in its physiological and behavioural conditions. Induced breeding in fishes will be significant for commercial seed production and it can be utilized for species restoration and conservation. Pethia manipurensis and Pethia khugae is also economically important for the preparation of two important fermented fish products of Manipur Hentak and Ngari. The culture of Devairo acuticephalus will help the fish farmers of Manipur to generate income and also to increase a better livelihood of the people. Devario aceuticephalus will be of model organism in future, because of the transparent nature of egg and easy to visible directly the organogenesis during early stages of development, which is the character of Zebra fish, a model organism.

\section{ACKNOWLEDGMENT}

The first author (Y. M.) is grateful to Department of Life Sciences Manipur, University for giving laboratory facility.

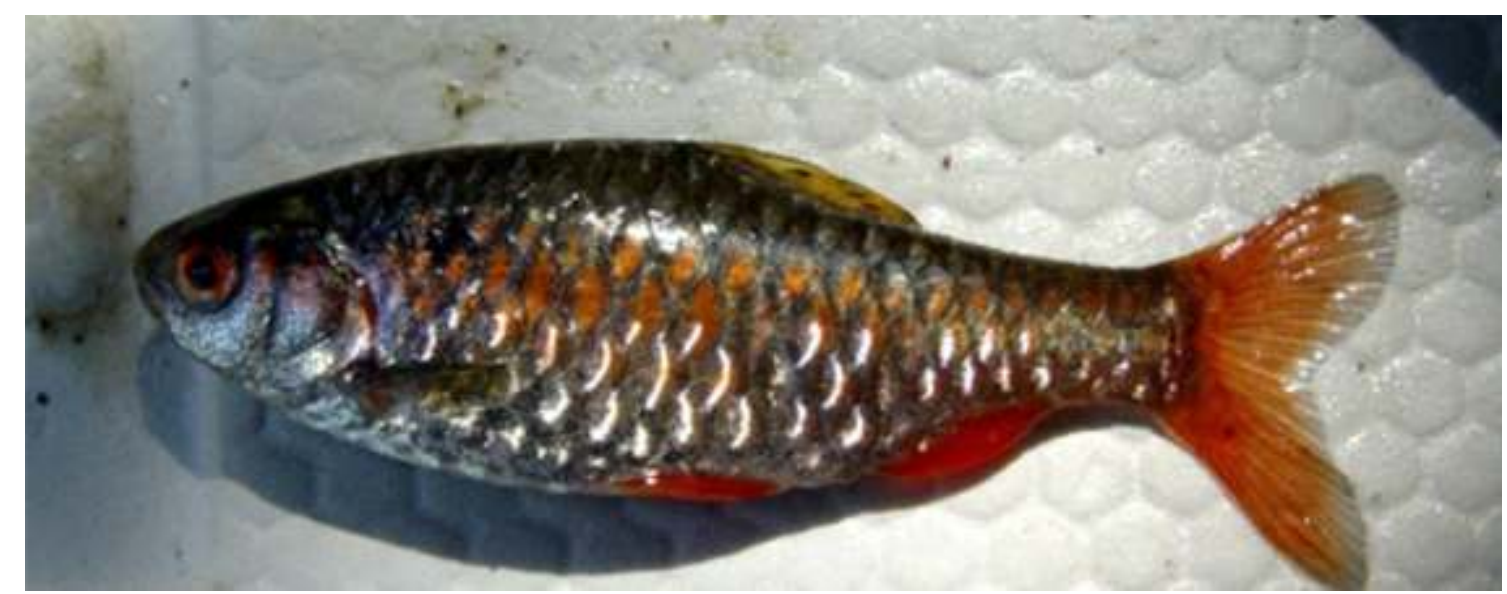

Fig. 2 Pethia manipurensis.

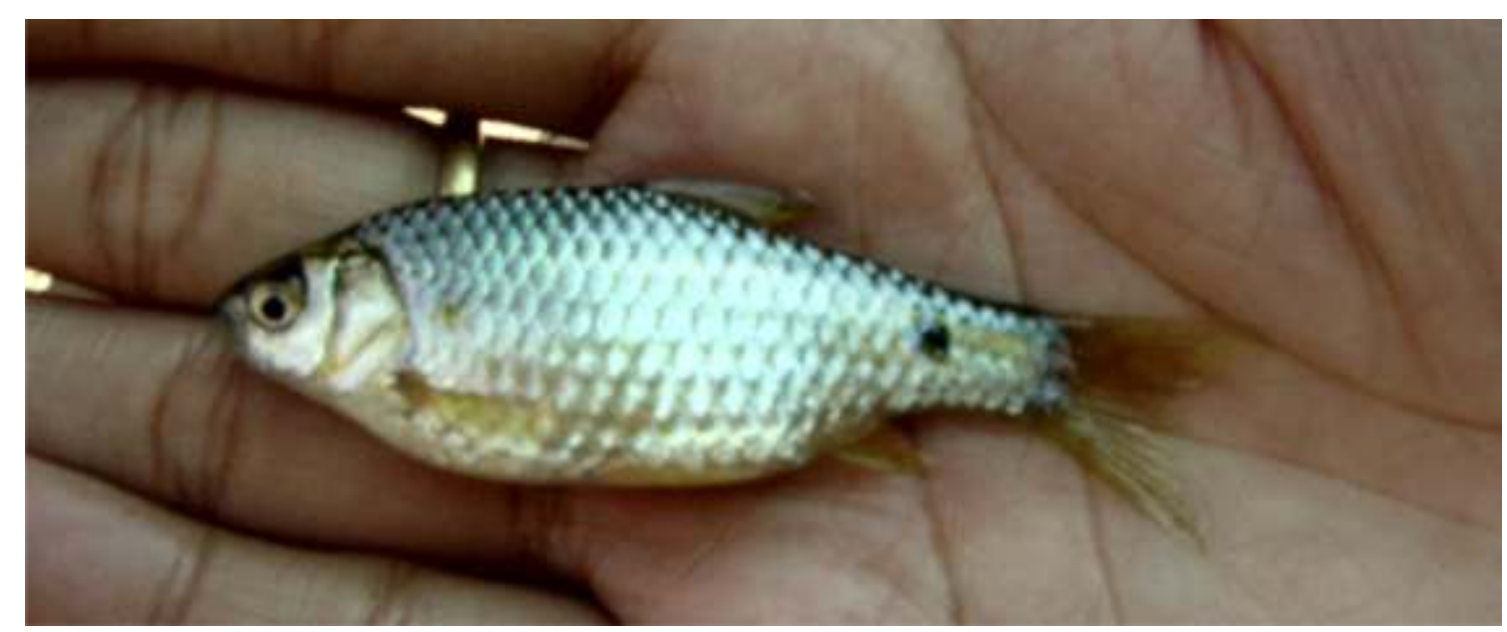

Fig. 3 Pethia khugae. 


\section{REFERENCES}

Clade, S.; Tamaru, B. Cole; B.; Bailey, R. and Brown (1997). A manual for commercial production of the Tiger Barbs, Copoetra tetrazona a temporary paired tank spawner. Centre for Tropical and Subtropical Aquaculture, no. 129.

Dawes, J. (2001). International aquatic industry perspectives on ornamental fish conservation. In : Conservation and Management of Ornamental Fish Resources of the Rio Nagro Basion, Amazonia, Brazil-Project Piaba (eds. Chao, N. L.; Perty, Prang, G., Sonneschein, L., Tlusty, M. F.). Editora da Universidadedo Amazonas, Manaus, Brazil, pp. 109-128.

Esther, J. J. and Vernallen, V. (2005). The Complete Encyclopaedia of Tropical Fishes. Hanberry Press, pp. 1-9.

Fang, F. and Kulander, O. S. (2009). Devrio xyrops, a species of danionine fish South Western Myanmar (Teliostei : Cyprinidae). Zootaxa, 216 :33-40.

Hora, S. L. (1921). Fish and fisheries of Manipur and some observations on those of the Naga hills. Records Indian Museum (Calcutta), 22 (pt.3,19) : 165-214, Pls. 9-12

Liley, N. R. and Tan, E. S. P. (1985). Artificial spawning behaviour in Puntius gonionatus (Bleeker) by treatment with prostaglandins PGF2. Journal of Fish Biology, $26:$ 491-502.

Linthoingambi, I. and Vishwanath, W. (2007). Two new fish species of the genus Puntius Hamilton (Cyprinidae) from Manipur with notes on P.ticto (Hamilton) and P.stoliczkanas (Day). Zootaxa, 1450 : 45-56.

Mani, C. V. and Pandy, A. K. (2007). Effect of HCG and WOVA-FH administration on ovarian maturation and spawning of Heteropnetus fossilis (Bloch). Journal of Experimental Zoology, India, 10 : 317-319.

Motilan, Y.; Bedajit, Y. and Vishwanath, W. (2013). Induced breeding of carp minnow Puntius chola (Hamilton,1822) with synthetic hormone WOVA-FH," NeBIO, 4(3): 21-23.

Ralston, A. and Shaw, K. (2008). Environmental controls of gene expression. Sex determination and the onset of genetic disorders. Nature Education, $1: 1$

Sarojnalini, Ch. and Vishwanath, W. (1988). Composition and digestibility of fermented fish foods of Manipur. Journal of Food Science Technology, 25(6) : 3493-3551.

Sukumaravin, N.; Leelapatra, W.; Lean, E. M. and Donaldson, E. M. (2006). Orally induced spawning of Thi carp Puntius goninotus (Bleeker) following co-administration of des Gly10 (D-Arg6)s GnRH Ethylamide and domperidone. Journal of Fish Biology, 40:477-479.

Tlusty, M. (2002). The benefits and risks of aquacultural production for the aquarium trade. Aquaculture, 205 : 203-219.

Vishwanath, W.; Lakra, L. and Sarkar, U. K. (2007). Fishes of North East India. National Bureau of Fish Genetic Resources (Indian Council of Agricultural Research), pp. 132.

Vishwanath, W.; Ng, H. H.; Britz, R.; Singh, L. K.; Shivaji, C. and Conway, K.W. (2010). The status and distribution of freshwater fishes of the Eastern Himalaya region. ICUN Red List, Status and distribution of freshwater biodiversity in the Eastern Himalaya, pp. 22-29.

Welch, P. S. (1948). Limnological methods. McGraw-Hill Book Cooperation, New York, USA, pp. 1-38.

Winkler, L. (1888). The Determination Oxygen in Water. Mathematikaiés Terészettedomanyi Ertessit, 6 : 273. 